\title{
Social Isolation, Inflammation, and Cancer Mortality from the National Health and Nutrition Examination Survey - A Study of 3,446 Women
}

\author{
Alexander Koh-Bell \\ Brown University \\ Joshua Chan \\ Stanford University \\ Amandeep K. Mann ( $\square$ manna1@sutterhealth.org ) \\ Palo Alto Medical Foundation Research Institute \\ Daniel S. Kapp \\ Stanford University School of Medicine
}

\section{Research Article}

Keywords: social network index, cancer mortality, c-reactive Protein, fibrinogen

Posted Date: March 11th, 2021

DOI: https://doi.org/10.21203/rs.3.rs-275389/v1

License: (c) (i) This work is licensed under a Creative Commons Attribution 4.0 International License.

Read Full License 


\section{Abstract}

\section{Background}

To evaluate the relationships of social isolation, inflammatory biomarkers, and cancer mortality among women.

\section{Methods}

Data were abstracted from the U.S. National Health and Nutrition Examination Survey from 1988-1994. The Social Network Index was used to assess participants' degree of social isolation. C-reactive protein and fibrinogen levels were included as markers of inflammation. We used the National Death Index to identify causes and dates of mortality. Chi-square and multivariable Cox regressions were employed for statistical analyses.

\section{Results}

Of 3,446 women (median age: 55 years), the most isolated, very isolated, somewhat isolated, and not isolated comprised $14.5 \%, 30.3 \%, 37.0 \%$, and $18.2 \%$ of the sample, respectively. The most isolated participants were more likely to have low income ( $57.1 \%$ vs $12.2 \%$, $p<0.001)$, have fewer years of education ( $40.6 \%$ vs $12.2 \%$; $p<0.001)$, have low physical activity $(27.3 \%$ vs $14.6 \% ; p<0.003)$, be obese (32.3\% vs $24.2 \% ; p=0.02)$, and be current smokers (33.8\% vs $10.2 \% ; p<0.001)$ compared to the not isolated ones. Mean fibrinogen levels increased with degree of social isolation $(p=0.02)$, but C-reactive protein showed no association $(p=0.58)$. Kaplan-Meier estimates indicated higher cancer mortality rates among participants with elevated fibrinogen levels, though not statistically significant $(p=0.07)$. Furthermore, there was no correlation between social isolation and cancer mortality $(p=0.55)$. On multivariate analysis, obesity $(\mathrm{HR}=1.39 ; 95 \% \mathrm{Cl}$ : 1.05-1.83; $\mathrm{p}=0.02)$ and lower education $(\mathrm{HR}=1.48 ; 95 \% \mathrm{Cl}$ : 1.04-2.11; $p=0.03$ ) were independent predictors for cancer mortality, while high physical activity predicted for lower mortality from cancer ( $\mathrm{HR}=0.67,95 \% \mathrm{Cl}$ : 0.49-0.91; $p=0.01)$. However, social isolation was not a predictor $(p=0.88)$.

\section{Conclusion}

Social isolation among women was associated with an increased level of fibrinogen, but not associated with cancer mortality. The relationship between inflammation and cancer mortality warrants further investigation.

\section{Background}

Social isolation, defined as a lack of interpersonal interaction, community engagement, and personal relationships, has been shown to be associated with higher inflammation as well as higher risk for mortality [1, 2]. After controlling for various mortality risk factors, several epidemiological studies have shown that the inflammatory biomarker C-reactive protein (CRP) was higher among socially isolated 
individuals [2, 3]. On the other hand, a study of Swedish men did not find a similar association between the inflammatory marker fibrinogen and social isolation [4]. Evaluating the relationship between cancer mortality and social isolation, multiple reports have shown increased cancer mortality in socially isolated individuals, but these results have differed between men and women [5-9].

Differences between men and women in inflammatory response may also contribute to the variation in these reports across sex [10]. Researchers have reported on the association of social isolation, inflammation, and mortality and found that social isolation was significantly correlated with cancer mortality in men, but not women [6]. In contrast, Marcus et al found this correlation between social isolation and cancer mortality to only hold for women [11]. However, this report did not adjust for inflammation or other health-related factors such as body mass index (BMI) and physical activity. While there is literature supporting the relationships between isolation and inflammation as well as inflammation and cancer, there are few multidisciplinary reports that assess the associations of these three topics [12].

Previous reports have indicated that inflammation may be a mediator in the relationship between social isolation and cancer mortality [6]. C-reactive protein (CRP) and fibrinogen are acute-phase proteins and markers of inflammation associated with cancer and cardiovascular disease. Studies indicate a correlation between CRP and cancer mortality, particularly for colorectal cancer [13]. The inflammatory marker fibrinogen has been shown to be associated with risk and prognosis of ovarian and other cancers $[14,15]$.

Due to the mixed findings reported by existing literature, an analysis is warranted to elucidate the relationships between social isolation, inflammatory biomarkers, and cancer mortality among women. In this report, we aim to clarify these relationships by analyzing baseline participant data along with rates of cancer mortality in a nationally representative sample of 3,446 women from the US National Health and Nutrition Examination Survey (NHANES).

\section{Methods}

\section{Data Source}

Our cohort consists of women of age 40 or above from the US National Health and Nutrition Examination Survey database from 1988-1994 (NHANES III). Due to the database's inclusion of fibrinogen data only among participants of age 40 and older, no younger participants were included in our cohort. NHANES is a cross-sectional examination survey conducted by the Centers for Disease Control and Prevention to evaluate the health and nutrition of the U.S. population [16]. This database includes information on demographics, health, and nutrition based on home interviews and physical examinations conducted in mobile examination centers (MEC). Participants who were 60 years and older, Mexican American, and Non-Hispanic Black were oversampled in the NHANES III database.

\section{Demographics and Behavioral Characteristics}


From this dataset, we abstracted age, race, income level, and education as our demographic factors, as well as BMI, self-reported health status, smoking status, and physical activity as behavioral factors. Age was dichotomized using the median age (55 years) of the overall sample and race was categorized as White, Black, Mexican American, or other. Education level was assessed by the highest grade or year of regular school that participants had completed. Additionally, participants' income level was determined by poverty income ratio (PIR), the ratio of family income to the poverty threshold adjusted by economic inflation. As defined by the U.S. Census, income levels are categorized as poverty: $\mathrm{PIR}<1$, low income: $1.0 \leq \mathrm{PIR}<2.0$, middle income: $2.0 \leq \mathrm{PIR}<4.0$, and high income: $\mathrm{PIR} \geq 4.0$. We have elected to include participants who were in poverty as members of the low-income group. Body mass index (BMI) was measured in the MEC and was categorized as either underweight (BMI<18.5), normal (BMI 18.5-24.5), overweight (BMI 25-29.5), or obese (BMI $\geq 30$ ) based on the Centers for Disease Control and Prevention categorization of BMI for adults. Self-reported health status was assessed by participant responses to the question, "Would you say your health in general is excellent, very good, good, fair, or poor?" Smoking status was identified as participants' current status as either non-smoker, former, or current smoker. Finally, physical activity was determined by how participants compare their physical activity to their peers.

\section{Social Network Index}

Social Network Index (SNI) is a measure of social isolation created by Berkman and Syme that evaluates individuals' marriage or partnership, support from friends or family, and religious or other group participation. An individual's SNI is defined by the number of the following criteria that they meet: married or living with a partner, having on average greater than 155 contacts or social interactions with family, friends, or neighbors per year, attending religious services more than 3 times per year, and involved in any club or organization such as a religious, fraternal, school, or athletic group. Home interviews took place with questions about these factors and answers were combined into a Social Network Index metric on a scale of 0 to 4 ( 0 being the highest level of isolation) [17]. We elected to combine individuals with a score of 0 or 1 and categorized them as 'Most Isolated'.

\section{Cancer Mortality and Exclusion Criteria}

We obtained data on causes and dates of mortality from the National Death Index (NDI) and used the International Classification of Diseases codes to determine underlying causes of death (C00-C97). Participants with baseline CRP measurements of $10 \mathrm{mg} / \mathrm{dL}$ and above were not reported in our study because these abnormally high CRP levels are often associated with influenza [11]. In addition, participants who had a history of cancer were excluded. The final sample consisted of 3,446 participants after incorporating the above exclusion criteria.

\section{Laboratory Analyses of Inflammatory Markers}

We analyzed NHANES measurements of two serum inflammatory biomarkers, C-reactive protein (CRP) and fibrinogen. These measurements were made from assessment of blood samples collected from NHANES participants. CRP levels were examined using latex-enhanced nephelometry, an analysis of light 
scattering of antigen-antibody complexes with latex particles. Fibrinogen levels were measured through thrombin clotting time, in which thrombin was used to enzymatically convert fibrinogen into fibrin [18]. In our analysis, CRP was categorized as a categorical variable. Because the majority (61\%) of participants in our study had CRP levels below the detection limit $(<0.22 \mathrm{mg} / \mathrm{dL})$, these participants were categorized as one group. Others with CRP levels at or above the detection level were dichotomized using a median value $(0.63 \mathrm{mg} / \mathrm{dL})$. Fibrinogen was treated as a continuous variable for the univariate and multivariate analysis. However, on Kaplan-Meier curves we categorized fibrinogen levels as $<200 \mathrm{mg} / \mathrm{dL}, 200-400$ $\mathrm{mg} / \mathrm{dL}$, and $>400 \mathrm{mg} / \mathrm{dL}$.

\section{Statistical Analysis}

Chi-square tests and t-tests were used to determine the associations between social isolation and all other collected baseline and demographic variables. To determine whether social isolation or any other factor was independently associated with cancer mortality, we performed multivariate analyses using adjusted Cox-proportional hazard models. In addition, multistage stratified, clustered probability, and sampling weights of the U.S. population were included in our analysis. Data analyses were conducted using SAS ${ }^{\circledR}$ Enterprise Guide 7.1 (SAS Institute Inc., Cary, NC, USA). This study was exempted from the IRB approval because it utilized a public-use data file and did not contain identifying information of the participants.

\section{Results}

Of 3,446 women (median age: 54 years; range: $40-89$ ), $81.1 \%$ were White, $8.9 \%$ were Black, $3.1 \%$ were Mexican American, and $6.9 \%$ were of another race. $26.3 \%$ of participants had education levels of high school or below, while $73.7 \%$ of participants had education levels above high school. Low, middle, and high-income levels were represented in $31.7 \%, 38.1 \%$, and $30.2 \%$ of participants, respectively. Additionally, $26.9 \%$ of participants were obese. Relative physical activity was divided into less active, about the same, and more active at $19.9 \%, 44.0 \%$, and $36.2 \%$, respectively. The sample included $19.9 \%$ participants who currently smoke tobacco, $25.8 \%$ who formerly smoked, and $54.3 \%$ who never smoked.

With respect to Social Network Index, $14.5 \%, 30.3 \%, 37.0 \%$, and $18.2 \%$ were most isolated, very isolated, somewhat isolated, and not isolated, respectively. Significant differences were found between isolated and non-isolated participants in demographic and other baseline variables. The not isolated group was more likely than the most isolated group to be of low income ( $57.1 \%$ vs $12.2 \%, p<0.001)$, have fewer than 12 years of education ( $40.6 \%$ vs $12.2 \%, p<0.001)$, be less physically active $(27.3 \%$ vs $14.6 \%, p=0.003)$, be obese $(32.3 \%$ vs $24.2 \%, p=0.02)$ and currently smoke (33.8\% vs $10.2 \%, p<0.001)$ (Table 1$)$. 
Table 1

Associated Characteristics by Social Network Index

\begin{tabular}{|c|c|c|c|c|c|c|}
\hline Characteristics & Overall & $\begin{array}{l}0 / 1=\text { Most } \\
\text { lsolated }\end{array}$ & $\begin{array}{l}2=\text { Very } \\
\text { Isolated }\end{array}$ & $\begin{array}{l}3= \\
\text { Somewhat } \\
\text { Isolated }\end{array}$ & $\begin{array}{l}4=\text { Not } \\
\text { Isolated }\end{array}$ & $\begin{array}{l}\mathrm{P}- \\
\text { value }\end{array}$ \\
\hline Overall N (\%) & $\begin{array}{l}N= \\
3,446\end{array}$ & $562(14.5 \%)$ & $1162(30.3 \%)$ & $1225(37.0 \%)$ & $497(18.2 \%)$ & \\
\hline Age & & & & & & $0.85^{\mathrm{a}}$ \\
\hline Median (range) & $\begin{array}{l}55 \\
(40- \\
89)\end{array}$ & $54(40-89)$ & $55(40-89)$ & $55(40-89)$ & $54(40-88)$ & \\
\hline Younger than 55 & $46.10 \%$ & $46.40 \%$ & $44.50 \%$ & $46.40 \%$ & $47.80 \%$ & \\
\hline $\begin{array}{l}55 \text { years and } \\
\text { older }\end{array}$ & $53.93 \%$ & $53.60 \%$ & $55.50 \%$ & $53.60 \%$ & $52.20 \%$ & \\
\hline Race/Ethnicity & & & & & & $\begin{array}{l}< \\
0.001^{\mathrm{a}}\end{array}$ \\
\hline White & $81.12 \%$ & $75.40 \%$ & $78.60 \%$ & $81.30 \%$ & $89.60 \%$ & \\
\hline Black & $8.92 \%$ & $9.30 \%$ & $10.50 \%$ & $8.80 \%$ & $6.20 \%$ & \\
\hline Mexican & $3.09 \%$ & $3.80 \%$ & $3.70 \%$ & $3.10 \%$ & $1.50 \%$ & \\
\hline Other $^{b}$ & $6.88 \%$ & $11.40 \%$ & $7.20 \%$ & $6.80 \%$ & $2.70 \%$ & \\
\hline Income Level & & & & & & $\begin{array}{l}< \\
0.001^{a}\end{array}$ \\
\hline Low Income & $31.68 \%$ & $57.10 \%$ & $38.10 \%$ & $26.00 \%$ & $12.20 \%$ & \\
\hline Middle Income & $38.12 \%$ & $30.50 \%$ & $37.30 \%$ & $38.20 \%$ & $45.50 \%$ & \\
\hline High Income & $30.20 \%$ & $12.40 \%$ & $24.60 \%$ & $35.90 \%$ & $42.30 \%$ & \\
\hline Education & & & & & & $\begin{array}{l}< \\
0.001^{a}\end{array}$ \\
\hline $\begin{array}{l}\text { Less than } 12 \\
\text { years }\end{array}$ & $26.33 \%$ & $40.60 \%$ & $33.10 \%$ & $22.10 \%$ & $12.20 \%$ & \\
\hline
\end{tabular}

Data are \% unless otherwise specified.

Note: percentages may not add up to 100 due to rounding

${ }^{a}$ Chi-square test was performed to calculate $p$-values between the two categorical variables

$\mathrm{b}$ Other race consists of mixed race, Asians, and any other race not specified in the NHANES III database

${ }^{\mathrm{c}} \mathrm{T}$-test was used to calculate $\mathrm{p}$-values for the mean differences of fibrinogen levels between the social network index groups 


\begin{tabular}{|c|c|c|c|c|c|c|}
\hline Characteristics & Overall & $\begin{array}{l}0 / 1=\text { Most } \\
\text { lsolated }\end{array}$ & $\begin{array}{l}2=\text { Very } \\
\text { Isolated }\end{array}$ & $\begin{array}{l}3= \\
\text { Somewhat } \\
\text { Isolated }\end{array}$ & $\begin{array}{l}4=\text { Not } \\
\text { Isolated }\end{array}$ & $\begin{array}{l}\mathrm{P}- \\
\text { value }\end{array}$ \\
\hline 12 years or more & $73.67 \%$ & $59.40 \%$ & $66.90 \%$ & $77.90 \%$ & $87.80 \%$ & \\
\hline Obese $\left(\mathrm{kg} / \mathrm{m}^{2}\right)$ & & & & & & $0.02^{\mathrm{a}}$ \\
\hline$<30.0 \mathrm{~kg} / \mathrm{m}^{2}$ & $73.10 \%$ & $67.70 \%$ & $70.70 \%$ & $76.00 \%$ & $75.80 \%$ & \\
\hline$\geq 30.0 \mathrm{~kg} / \mathrm{m}^{2}$ & $26.90 \%$ & $32.30 \%$ & $29.30 \%$ & $24.00 \%$ & $24.20 \%$ & \\
\hline Smoking Status & & & & & & $\begin{array}{l}<.001^{\mathrm{a}} \\
\end{array}$ \\
\hline Nonsmoker & $54.26 \%$ & $38.60 \%$ & $47.30 \%$ & $61.90 \%$ & $62.80 \%$ & \\
\hline Former & $25.83 \%$ & $27.50 \%$ & $27.30 \%$ & $23.40 \%$ & $27.00 \%$ & \\
\hline Current & $19.91 \%$ & $33.80 \%$ & $25.40 \%$ & $14.70 \%$ & $10.20 \%$ & \\
\hline Physical Activity & & & & & & $0.003^{a}$ \\
\hline About the Same & $43.95 \%$ & $36.80 \%$ & $45.20 \%$ & $43.70 \%$ & $48.10 \%$ & \\
\hline Less Active & $19.88 \%$ & $27.30 \%$ & $22.20 \%$ & $17.70 \%$ & $14.60 \%$ & \\
\hline Most Active & $36.17 \%$ & $35.90 \%$ & $32.60 \%$ & $38.60 \%$ & $37.30 \%$ & \\
\hline $\begin{array}{l}\text { Self-Reported } \\
\text { Health Status }\end{array}$ & & & & & & $0.001^{a}$ \\
\hline Poor & $32.40 \%$ & $23.60 \%$ & $30.00 \%$ & $35.80 \%$ & $36.70 \%$ & \\
\hline Fair & $27.70 \%$ & $29.30 \%$ & $27.40 \%$ & $26.60 \%$ & $29.00 \%$ & \\
\hline Good & $29.20 \%$ & $29.00 \%$ & $31.80 \%$ & $27.80 \%$ & $28.20 \%$ & \\
\hline Very Good & $9.10 \%$ & $14.50 \%$ & $9.10 \%$ & $8.50 \%$ & $5.70 \%$ & \\
\hline Excellent & $1.60 \%$ & $3.70 \%$ & $1.70 \%$ & $1.30 \%$ & $0.30 \%$ & \\
\hline $\begin{array}{l}\text { C-Reactive } \\
\text { Protein }(\mathrm{mg} / \mathrm{dL})\end{array}$ & & & & & & $0.58^{\mathrm{a}}$ \\
\hline$\leq 0.21 \mathrm{mg} / \mathrm{dL}$ & $61.20 \%$ & $60.20 \%$ & $60.00 \%$ & $61.60 \%$ & $63.50 \%$ & \\
\hline
\end{tabular}

Data are \% unless otherwise specified.

Note: percentages may not add up to 100 due to rounding

${ }^{a}$ Chi-square test was performed to calculate $p$-values between the two categorical variables

b Other race consists of mixed race, Asians, and any other race not specified in the NHANES III database

${ }^{c}$ T-test was used to calculate $p$-values for the mean differences of fibrinogen levels between the social network index groups 


\begin{tabular}{|c|c|c|c|c|c|c|}
\hline Characteristics & Overall & $\begin{array}{l}0 / 1=\text { Most } \\
\text { Isolated }\end{array}$ & $\begin{array}{l}2=\text { Very } \\
\text { Isolated }\end{array}$ & $\begin{array}{l}3= \\
\text { Somewhat } \\
\text { Isolated }\end{array}$ & $\begin{array}{l}4=\text { Not } \\
\text { Isolated }\end{array}$ & $\begin{array}{l}\mathrm{P}- \\
\text { value }\end{array}$ \\
\hline $\begin{array}{l}0.22-0.63 \\
\mathrm{mg} / \mathrm{dL}\end{array}$ & $18.60 \%$ & $20.10 \%$ & $17.60 \%$ & $18.10 \%$ & $19.90 \%$ & \\
\hline$>0.63 \mathrm{mg} / \mathrm{dL}$ & $20.20 \%$ & $19.80 \%$ & $22.40 \%$ & $20.30 \%$ & $16.60 \%$ & \\
\hline $\begin{array}{l}\text { Fibrinogen } \\
(\mathrm{mg} / \mathrm{dL})\end{array}$ & 308 & 319 & 312 & 309 & 289 & $0.002^{c}$ \\
\hline \multicolumn{7}{|c|}{ Data are \% unless otherwise specified. } \\
\hline \multicolumn{7}{|c|}{$\begin{array}{l}\text { Note: percentages may not add up to } 100 \text { due to rounding } \\
\text { a Chi-square test was performed to calculate p-values between the two categorical variables } \\
\text { b Other race consists of mixed race, Asians, and any other race not specified in the NHANES III } \\
\text { database } \\
{ }^{c} \text { T-test was used to calculate p-values for the mean differences of fibrinogen levels between the } \\
\text { social network index groups }\end{array}$} \\
\hline
\end{tabular}

We evaluated the correlations between social isolation and both fibrinogen and CRP levels through Chisquare analyses. Fibrinogen levels consistently increased across Social Network Index categories from least to most isolated, with mean fibrinogen measurements of $289.41 \mathrm{mg} / \mathrm{dL}, 308.8 \mathrm{mg} / \mathrm{dL}, 312.01$ $\mathrm{mg} / \mathrm{dL}$, and $318.83 \mathrm{mg} / \mathrm{dL}$, respectively $(\mathrm{p}=0.002)$ (Fig. 1). No significant association was found between social isolation and CRP level (Fig. 2) (Table 1).

Kaplan-Meier analysis did not show a relationship between CRP levels and cancer mortality $(p=0.56)$ (Fig. 3). While not statistically significant, participants with high fibrinogen measurements $(>400 \mathrm{mg} / \mathrm{dL})$ appeared to have higher cancer mortality rates than those with lower fibrinogen measurements $(<200$ $\mathrm{mg} / \mathrm{dL}$ and $200-400 \mathrm{mg} / \mathrm{dL})(p=0.07)$ (Fig. 4). In addition, there was no association between degree of social isolation and cancer mortality $(p=0.55)($ Fig. 5).

On multivariate analysis, obesity $(H R=1.39 ; 95 \% \mathrm{Cl}: 1.05-1.83 ; p=0.02)$ and lower education $(H R=1.48$; $95 \% \mathrm{Cl}: 1.04-2.11 ; \mathrm{p}=0.03$ ) were independent predictors for cancer mortality, while high physical activity independently predicted for lower cancer mortality ( $\mathrm{HR}=0.67 ; 95 \% \mathrm{Cl}: 0.49-0.91 ; \mathrm{p}=0.01)$. However, social isolation was not independently associated with cancer mortality after adjusting for demographic, socioeconomic and behavioral factors ( $\mathrm{HR}=1.07 ; 95 \% \mathrm{Cl}: 0.42-2.72 ; \mathrm{p}=0.88)$. In addition, both elevated $\operatorname{CRP}(H R=0.98 ; 95 \% \mathrm{Cl}: 0.50-1.91 ; p=0.95)$ and fibrinogen $(H R=1.001 ; 95 \% \mathrm{Cl}: 1.00-1.004 ; p=0.27)$ levels were not independently associated with cancer mortality (Table 2). 
Table 2

Multivariate Cox Proportional Hazard Model of Associated Factors with Cancer Mortality

\section{Characteristics}

Social Network Index

$4=$ Not Isolated

$3=$ Somewhat isolated

$2=$ Very Isolated

$0 / 1=$ Most Isolated

Race/Ethnicity

White

Black

Mexican

Other $^{\mathrm{a}}$

Income Level

Low Income

Middle Income

High Income

Education

Less than 12 years

12 years or more

Obese $\left(\mathrm{kg} / \mathrm{m}^{2}\right)$

$<30.0 \mathrm{~kg} / \mathrm{m}^{2}$

$\geq 30.0 \mathrm{~kg} / \mathrm{m}^{2}$

Physical Activity

About the Same

Less Active

Most Active
Hazard Ratio 95\% Confidence Interval

P-value 1

0.73

1.01

1.07

$0.42-2.72$

1

1.35

$0.86-2.10$

0.18

0.98

$0.63-1.54$

0.94

1.13

$0.33-3.84$

0.84
0.88

0.22

0.97 


\begin{tabular}{|c|c|c|c|}
\hline Characteristics & Hazard Ratio & 95\% Confidence Interval & P-value \\
\hline \multicolumn{4}{|c|}{ Self-Reported Health Status } \\
\hline Excellent & 1 & & \\
\hline Very Good & 1.29 & $0.71-2.34$ & 0.4 \\
\hline Good & 1.22 & $0.75-1.98$ & 0.42 \\
\hline Fair & 0.77 & $0.38-1.54$ & 0.45 \\
\hline Poor & 0.27 & $0.07-1.06$ & 0.06 \\
\hline \multicolumn{4}{|c|}{ C-Reactive Protein (mg/dL) } \\
\hline$\leq 0.21 \mathrm{mg} / \mathrm{dL}$ & 1 & & \\
\hline $0.22-0.63 \mathrm{mg} / \mathrm{dL}$ & 0.99 & $0.67-1.47$ & 0.96 \\
\hline$>0.63 \mathrm{mg} / \mathrm{dL}$ & 0.98 & $0.50-1.91$ & 0.95 \\
\hline Fibrinogen (mg/dL) & 1.001 & $1.00-1.004$ & 0.27 \\
\hline
\end{tabular}

\section{Discussion}

Social isolation has been shown to be associated with inflammatory biomarker levels [1, 2]. Moreover, social isolation may lead to increased risk for cancer mortality [11]. However, the impact of social isolation in women may differ from that in men, particularly in relation to inflammatory response and cancer mortality $[6-9,13]$. In our analysis of 3,446 adult females based on a large, nationally representative survey, we found that socially isolated participants were more likely to have lower socioeconomic status, lower rates of physical activity, and higher rates of obesity and smoking. Lack of social connectedness was also associated with heightened levels of serum fibrinogen, but not CRP. Although Kaplan-Meier estimates indicated higher cancer mortality rates for participants with elevated fibrinogen levels, there was no statistically significant association between the two. Furthermore, there was no significant relationship between social isolation and cancer mortality after adjusting for demographic, socioeconomic, and behavioral risk factors.

In our study, we found a direct correlation between the degree of social isolation and fibrinogen levels. Similarly, the Framingham Offspring Study group by Kim et al. found elevated fibrinogen levels in those with less social connection [12]. In addition, Nersesian et al. found high fibrinogen levels to be strongly associated with more socially isolated, middle-aged men and women [19]. Prior studies have investigated the potential mechanisms underlying the relationship between social isolation and inflammation. This relationship may be mediated by increased psychological stress in isolated individuals, which is correlated with heightened inflammation [20-22]. Loneliness may activate the sympathetic nervous 
system and Hypothalamic Pituitary Adrenocortical (HPA) axis, both of which are critical components to the body's stress response $[23,24]$. Furthermore, dysregulation of the HPA-axis may be associated with chronic stress and subsequently higher inflammation levels [25]. Researchers have also suggested that social isolation may result in heightened inflammatory sensitivity to biological and social stressors, resulting in elevated inflammation among isolated individuals [26].

Conversely, it is also possible that inflammation can induce social withdrawal. Raison and Miller suggest that inflammatory cytokines activate conservation and withdrawal behavior through the basal ganglia [27]. More specifically, the inflammatory cytokines induce a "sickness behavior," including social withdrawal, that provide an adaptive defense mechanism to protect against infection by avoiding exposures and conserving energy [28]. Furthermore, the expression of the neuropeptide $Y$ gene has been shown to be correlated with inflammation as well as social isolation and major depressive disorder [2931].

Prior studies have shown a correlation between CRP and social integration [21, 32]. Similarly, in a New England regional study of over 2000 adults, these authors concluded that the least socially integrated individuals had a twofold or higher risk of elevated CRP levels compared to the most socially integrated [33]. However, these studies evaluated social isolation and CRP among men and women. In contrast, prior studies have not shown a significant correlation between social isolation and CRP levels solely in women $[2,3]$. Further studies are warranted to investigate the biological role of sex in the relationship between isolation and CRP level.

In this current report, elevated fibrinogen levels appeared to be associated with higher cancer mortality among women, though not statistically significant. However, on multivariate analysis, both CRP and fibrinogen were not independent predictors for cancer mortality. Similarly, Wulaningsih et al. was unable to demonstrate a significant association between CRP levels and cancer mortality in women, but the authors did find this relationship in their male cohort [34]. In a study of over 10,000 women, GathiruaMwangi and colleagues also did not find a correlation between CRP and cancer mortality [35]. The sex differences from these studies may be explained by the reported lower levels of cortisol levels in women in response to stress compared to men [11,36,37]. Kudielka and Kirschbaum showed that women under stress have less activation of the HPA-axis compared to men and thus have lower levels of inflammation [37]. Furthermore, Taylor and colleagues reported that women are more likely to seek out social support in response to social stress, whereas men tend to exhibit a fight-or-flight stress response [38]. Different biological responses to social stress between men and women may contribute to the statistically insignificant relationship between cancer mortality and inflammation in our female cohort.

While we found social isolation to be correlated with multiple potential risk factors for cancer, including heightened fibrinogen levels, increased obesity and smoking levels, as well as low physical activity and socioeconomic status, we found no association between social isolation and rate of cancer mortality. In contrast to our findings, Reynolds and Kaplan found higher rates of cancer mortality in socially isolated women in a regional sample of 6,848 adults [39]. However, this study did not adjust for inflammation and 
physical activity. In a meta-analysis of 40 observational studies, Leigh-Hunt et al. found that social isolation was correlated with poor cardiovascular and mental health outcomes, but not cancer mortality [40]. Thus, social isolation in relation to cancer mortality and its underlying mechanisms warrants further investigation.

Our results may not be generalizable due to the following limitations. Our sample was restricted to 19881994 due to the limited span of Social Network Index scores collected by NHANES. Due to the crosssectional nature of our study, we were unable to offer insight into how changes over time in factors such as social isolation and inflammation impacted our participants' health outcomes. In addition, we were unable to obtain information on cancer incidence, tumor type, stage of disease, treatment and survival time after diagnosis. The incidence and outcomes of certain cancers may be related to inflammation, while others may be predominantly related to other causes. For example, incidence and outcomes are largely related to carcinogens in smoking-related cancers. By including all cancer types, we may not be able to detect associations between certain subsets of malignancy and inflammation. Moreover, the surveys did not focus on factors related to social isolation such as feelings of loneliness, stress, or depression, which may affect cancer mortality. However, our report is a cross-disciplinary study that relates social behavior, immunology, and oncology. To our knowledge, this is one of the few studies that evaluated the impact of social isolation in women in relation to inflammatory markers and cancer mortality. Furthermore, we were able to perform our analysis in a multivariate model adjusting for important demographic, socioeconomic and behavioral factors.

\section{Conclusions}

Our data showed that social isolation among women was associated with an increased level of fibrinogen, but not associated with cancer mortality. The correlation between inflammation and cancer mortality warrants further investigation. Novel inflammatory biomarkers and metrics for social isolation may further enhance our understanding of the relationship among social disconnectedness, inflammation and cancer mortality.

\section{Abbreviations}

CRP: C-reactive protein

BMl: Body mass index

NHANES: National Health and Nutrition Examination Survey

MEC: Mobile Examination Center

PIR: Poverty income ratio

SNI: Social Network Index 
NDI: National Death Index

IRB: Institutional Review Board

HR: Hazard ratio

Cl: Confidence interval

HPA: Hypothalamic Pituitary Adrenocortical

\section{Declarations}

\section{Ethics approval and consent to participate}

Not applicable.

\section{Consent for publication}

Not applicable.

\section{Availability of data and materials}

The datasets generated and/or analyzed during the current study are publicly available in the NHANES repository, (https://wwwn.cdc.gov/nchs/nhanes/Default.aspx).

\section{Competing interests}

All authors declare no conflict of interest.

\section{Funding}

Not applicable.

\section{Acknowledgements}

We would like to acknowledge Denise Cobb Hale, The Fisher Family Fund, and John K. Chan for their generous administrative support.

\section{Author's contributions}


All authors have equally contributed in the conceptions of this study (AK, JEC, AKM, and DSK). AKM acquired and downloaded the public-use datasets from NHANES, as well as managed and analyzed the data for the study. AK, JEC, AKM, and DSK interpreted data results, drafted the manuscript, and gave critical revision.

\section{References}

1. Pantell M, Rehkopf D, Jutte D, Syme SL, Balmes J, Adler N. Social isolation: a predictor of mortality comparable to traditional clinical risk factors. Am J Public Health. 2013 Nov;103(11):2056-62.

2. Ford ES, Loucks EB, Berkman LF. Social Integration and Concentrations of C-reactive Protein Among US Adults. Annals of epidemiology. 2006.

3. Loucks EB, Berkman LF, Gruenewald TL, Seeman TE. Relation of social integration to inflammatory marker concentrations in men and women 70 to 79 years. Am J Cardiol. 2006 Apr 1;97(7):1010-6.

4. Orth-Gomér K, Rosengren A, Wilhelmsen L. Lack of social support and incidence of coronary heart disease in middle-aged Swedish men. Psychosom Med. 1993 Feb;55(1):37-43.

5. House JS, Robbins C, Metzner HL. The association of social relationships and activities with mortality: prospective evidence from the Tecumseh Community Health Study. Am J Epidemiol. 1982 Jul;116(1):123-40.

6. Yang YC, McClintock MK, Kozloski M, Li T. Social isolation and adult mortality: the role of chronic inflammation and sex differences. J Health Soc Behav. 2013 Jun;54(2):183-203.

7. Lutgendorf SK, De Geest K, Bender D, Ahmed A, Goodheart MJ, Dahmoush L, et al. Social influences on clinical outcomes of patients with ovarian cancer. J Clin Oncol. 2012 Aug 10;30(23):2885-90.

8. Hinzey A, Gaudier-Diaz MM, Lustberg MB, DeVries AC. Breast cancer and social environment: getting by with a little help from our friends. Breast Cancer Res. 2016 26;18(1):54.

9. Patterson AC. Does the mortality risk of social isolation depend upon socioeconomic factors? J Health Psychol. 2016;21(10):2420-33.

10. Traustadóttir T, Bosch PR, Matt KS. Gender differences in cardiovascular and hypothalamic-pituitaryadrenal axis responses to psychological stress in healthy older adult men and women. Stress. 2003 Jun;6(2):133-40.

11. Fleisch Marcus A, Illescas AH, Hohl BC, Llanos AAM. Relationships between social isolation, neighborhood poverty, and cancer mortality in a population-based study of US adults. PLoS ONE. 2017;12(3):e0173370.

12. Kim DA, Benjamin EJ, Fowler JH, Christakis NA. Social connectedness is associated with fibrinogen level in a human social network. Proc Biol Sci. 2016 Aug 31;283(1837):20160958. doi: 10.1098/rspb.2016.0958.

13. Goyal A, Terry MB, Jin Z, Siegel AB. C-reactive protein and colorectal cancer mortality in U.S. adults. Cancer Epidemiol Biomarkers Prev. 2014 Aug;23(8):1609-18. 
14. Qiu J, Yu Y, Fu Y, Ye F, Xie X, Lu W. Preoperative plasma fibrinogen, platelet count and prognosis in epithelial ovarian cancer. J Obstet Gynaecol Res. 2012 Apr;38(4):651-7.

15. Lu DY, Chen XL, Cao JY, Li Z, Xue HW, Luo LJ, et al. Effects of cancer chemotherapy on the blood fibrinogen concentrations of cancer patients. J Int Med Res. 2000 Dec;28(6):313-7.

16. NHANES - National Health and Nutrition Examination Survey Homepage [Internet]. 2020 [cited 2020 Aug 7]. Available from: https://www.cdc.gov/nchs/nhanes/index.htm

17. NHANES 2005-2006: Social Support Data Documentation, Codebook, and Frequencies [Internet]. [cited 2020 Jul 2]. Available from: https://wwwn.cdc.gov/nchs/nhanes/2005-2006/SSQ_D.htm

18. NHANES III (1988-1994) [Internet]. [cited 2020 Jul 2]. Available from: https://wwwn.cdc.gov/nchs/nhanes/nhanes3/default.aspx

19. Nersesian PV, Han H-R, Yenokyan G, Blumenthal RS, Nolan MT, Hladek MD, et al. Loneliness in middle age and biomarkers of systemic inflammation: Findings from Midlife in the United States. Soc Sci Med. 2018;209:174-81.

20. Wirtz PH, von Känel R. Psychological Stress, Inflammation, and Coronary Heart Disease. Curr Cardiol Rep. 2017 20;19(11):111.

21. Yang YC, Li T, Frenk SM. Social network ties and inflammation in U.S. adults with cancer. Biodemography Soc Biol. 2014;60(1):21-37.

22. Shankar A, McMunn A, Banks J, Steptoe A. Loneliness, social isolation, and behavioral and biological health indicators in older adults. Health Psychol. 2011 Jul;30(4):377-85.

23. Eisenberger NI, Cole SW. Social neuroscience and health: neurophysiological mechanisms linking social ties with physical health. Nat Neurosci. 2012 Apr 15;15(5):669-74.

24. Eisenberger NI, Moieni M, Inagaki TK, Muscatell KA, Irwin MR. In Sickness and in Health: The CoRegulation of Inflammation and Social Behavior. Neuropsychopharmacology. 2017;42(1):242-53.

25. Hänsel A, Hong S, Cámara RJA, von Känel R. Inflammation as a psychophysiological biomarker in chronic psychosocial stress. Neurosci Biobehav Rev. 2010 Sep;35(1):115-21.

26. Smith KJ, Gavey S, RIddell NE, Kontari P, Victor C. The association between loneliness, social isolation and inflammation: A systematic review and meta-analysis. Neurosci Biobehav Rev. 2020;112:519-41.

27. Raison $\mathrm{CL}$, Miller AH. The evolutionary significance of depression in Pathogen Host Defense (PATHOS-D). Mol Psychiatry. 2013 Jan;18(1):15-37.

28. Eisenberger NI, Inagaki TK, Mashal NM, Irwin MR. Inflammation and social experience: an inflammatory challenge induces feelings of social disconnection in addition to depressed mood. Brain Behav Immun. 2010 May;24(4):558-63.

29. Chandrasekharan B, Nezami BG, Srinivasan S. Emerging neuropeptide targets in inflammation: NPY and VIP. Am J Physiol Gastrointest Liver Physiol. 2013 Jun 1;304(11):G949-957.

30. Heilig M, Zachrisson O, Thorsell A, Ehnvall A, Mottagui-Tabar S, Sjögren M, et al. Decreased cerebrospinal fluid neuropeptide Y (NPY) in patients with treatment refractory unipolar major 
depression: preliminary evidence for association with preproNPY gene polymorphism. J Psychiatr Res. 2004 Apr;38(2):113-21.

31. Mickey BJ, Zhou Z, Heitzeg MM, Heinz E, Hodgkinson CA, Hsu DT, et al. Emotion processing, major depression, and functional genetic variation of neuropeptide Y. Arch Gen Psychiatry. 2011 Feb;68(2):158-66.

32. Yang YC, Boen C, Gerken K, Li T, Schorpp K, Harris KM. Social relationships and physiological determinants of longevity across the human life span. Proc Natl Acad Sci USA. 2016 Jan 19;113(3):578-83.

33. Heffner KL, Waring ME, Roberts MB, Eaton CB, Gramling R. Social isolation, C-reactive protein, and coronary heart disease mortality among community-dwelling adults. Soc Sci Med. 2011 May;72(9):1482-8.

34. Wulaningsih W, Holmberg L, Ng T, Rohrmann S, Van Hemelrijck M. Serum leptin, C-reactive protein, and cancer mortality in the NHANES III. Cancer Med. 2016 Jan;5(1):120-8.

35. Gathirua-Mwangi WG, Song Y, Monahan PO, Champion VL, Zollinger TW. Associations of metabolic syndrome and C-reactive protein with mortality from total cancer, obesity-linked cancers and breast cancer among women in NHANES III. Int J Cancer. 2018 01;143(3):535-42.

36. Moreno-Smith M, Lutgendorf SK, Sood AK. Impact of stress on cancer metastasis. Future Oncol. 2010 Dec;6(12):1863-81.

37. Kudielka BM, Kirschbaum C. Sex differences in HPA axis responses to stress: a review. Biol Psychol. 2005 Apr;69(1):113-32.

38. Taylor SE, Klein LC, Lewis BP, Gruenewald TL, Gurung RA, Updegraff JA. Biobehavioral responses to stress in females: tend-and-befriend, not fight-or-flight. Psychol Rev. 2000 Jul;107(3):411-29.

39. Reynolds P, Kaplan GA. Social connections and risk for cancer: prospective evidence from the Alameda County Study. Behav Med. 1990;16(3):101-10.

40. Leigh-Hunt N, Bagguley D, Bash K, Turner V, Turnbull S, Valtorta N, et al. An overview of systematic reviews on the public health consequences of social isolation and loneliness. Public Health. 2017 Nov;152:157-71.

\section{Figures}




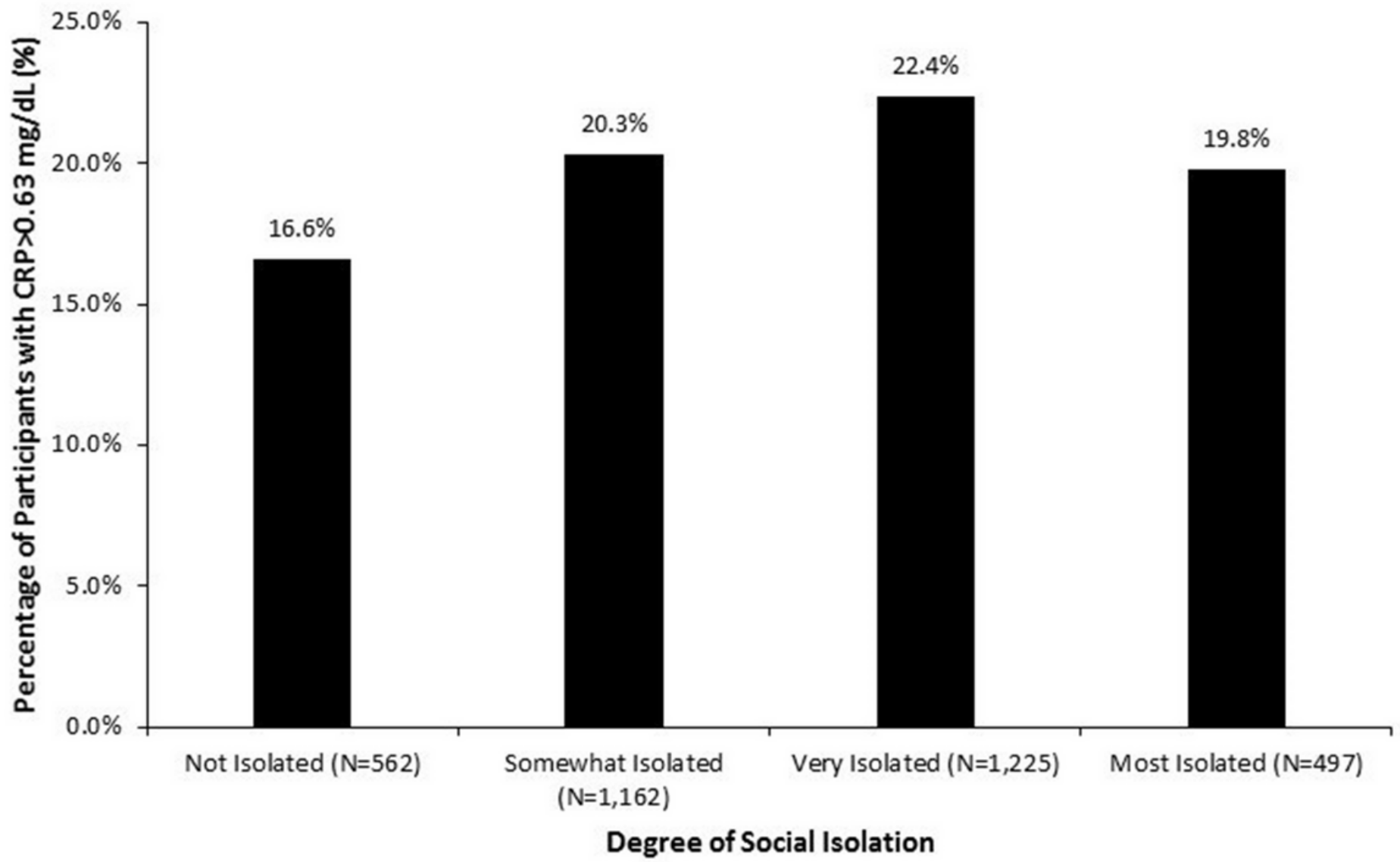

Figure 1

Association between Social Network Index and C-Reactive Protein $(p=0.58)$ 


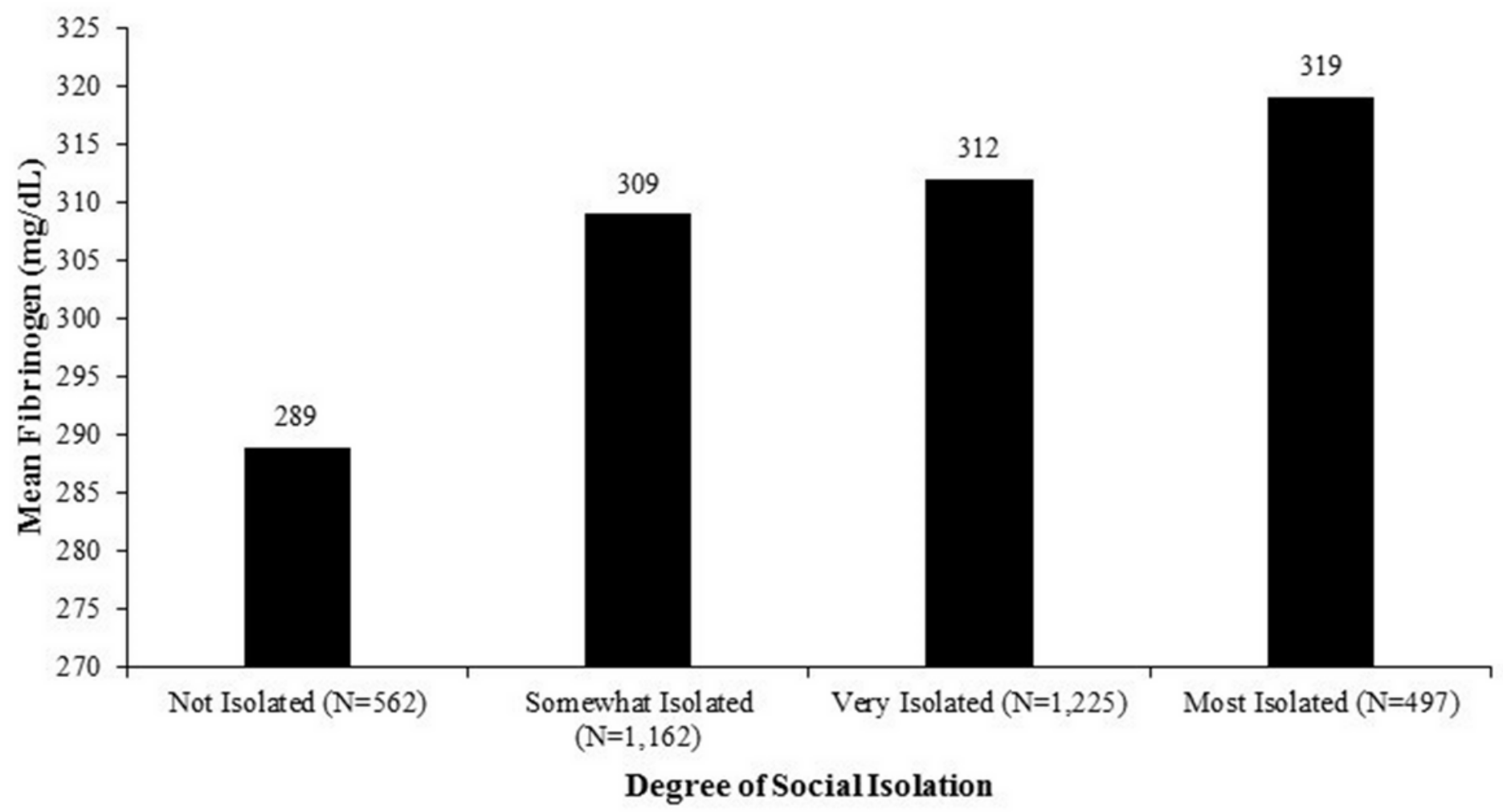

Figure 2

Association between Social Network Index and Fibrinogen $(p=0.002)$ 


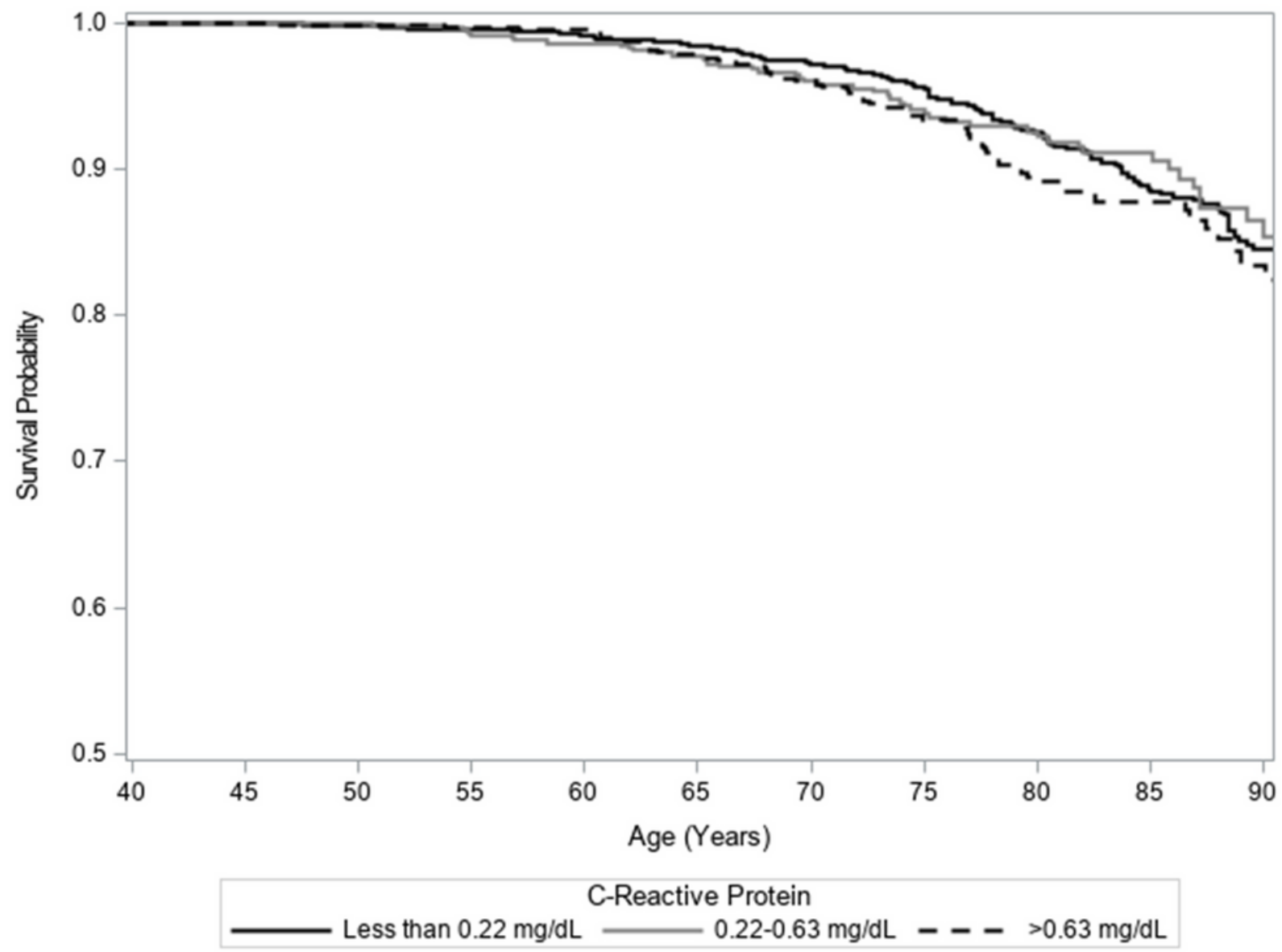

Total $\mathrm{n}=3446 . \mathrm{n}=1925$ for $\mathrm{CRP}<0.22 \mathrm{mg} / \mathrm{dL}, \mathrm{n}=677$ for $0.22-0.63 \mathrm{mg} / \mathrm{dL}, \mathrm{n}=844$ for $>0.63 \mathrm{mg} / \mathrm{dL}$.

Figure 3

Kaplan-Meier Estimates of Cancer Mortality by Baseline Level of C-Reactive Protein $(\log$-rank $p=0.56)$ 


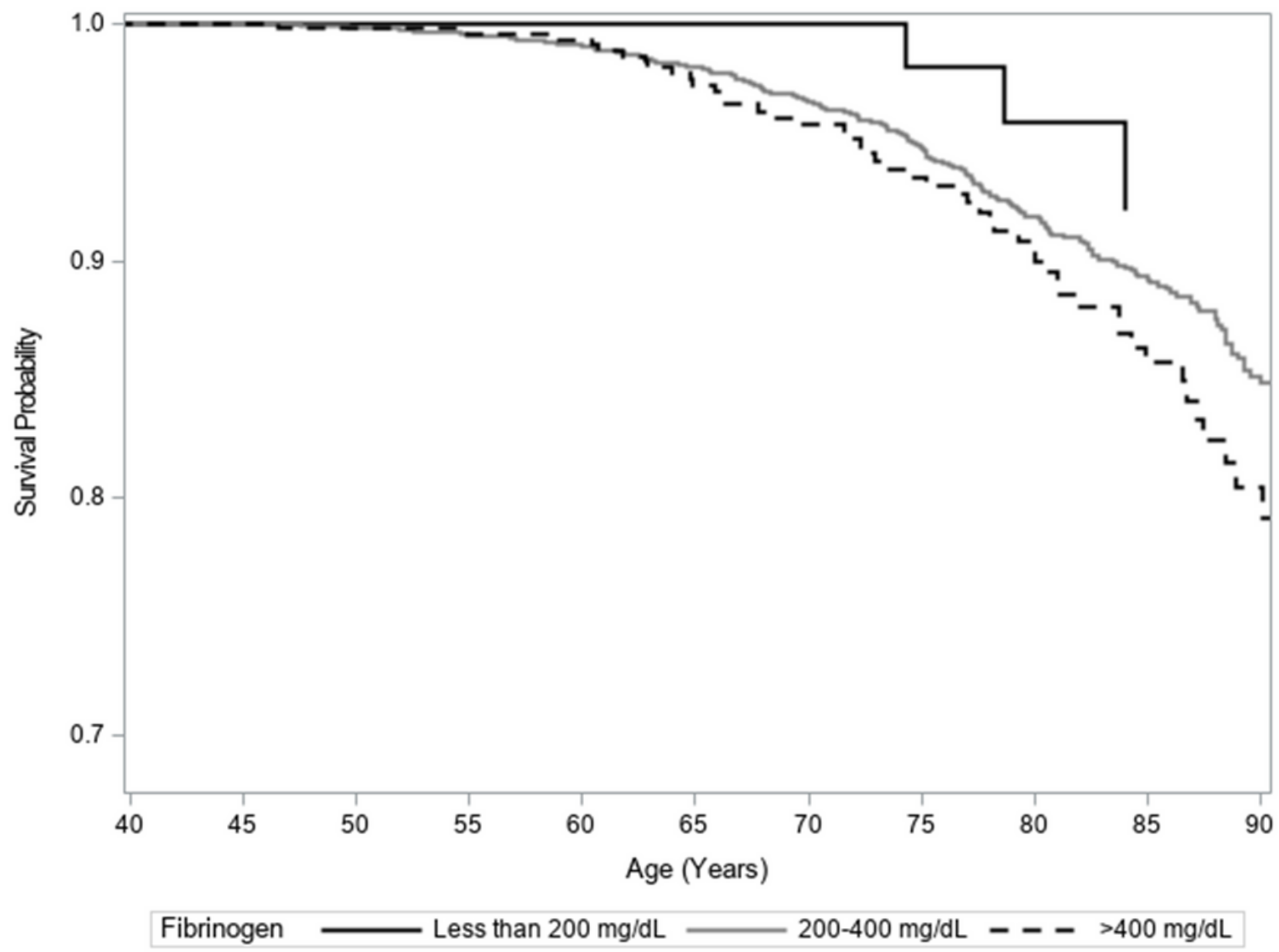

Total $\mathrm{n}=3466 . \mathrm{n}=118$ for fibrinogen $<200 \mathrm{mg} / \mathrm{dL}, \mathrm{n}=2865$ for $200-400 \mathrm{mg} / \mathrm{dL}, \mathrm{n}=463$ for $>400 \mathrm{mg} / \mathrm{dL}$.

Figure 4

Kaplan-Meier Estimates of Cancer Mortality by Baseline Level of Fibrinogen (log-rank $p=0.07$ ) 


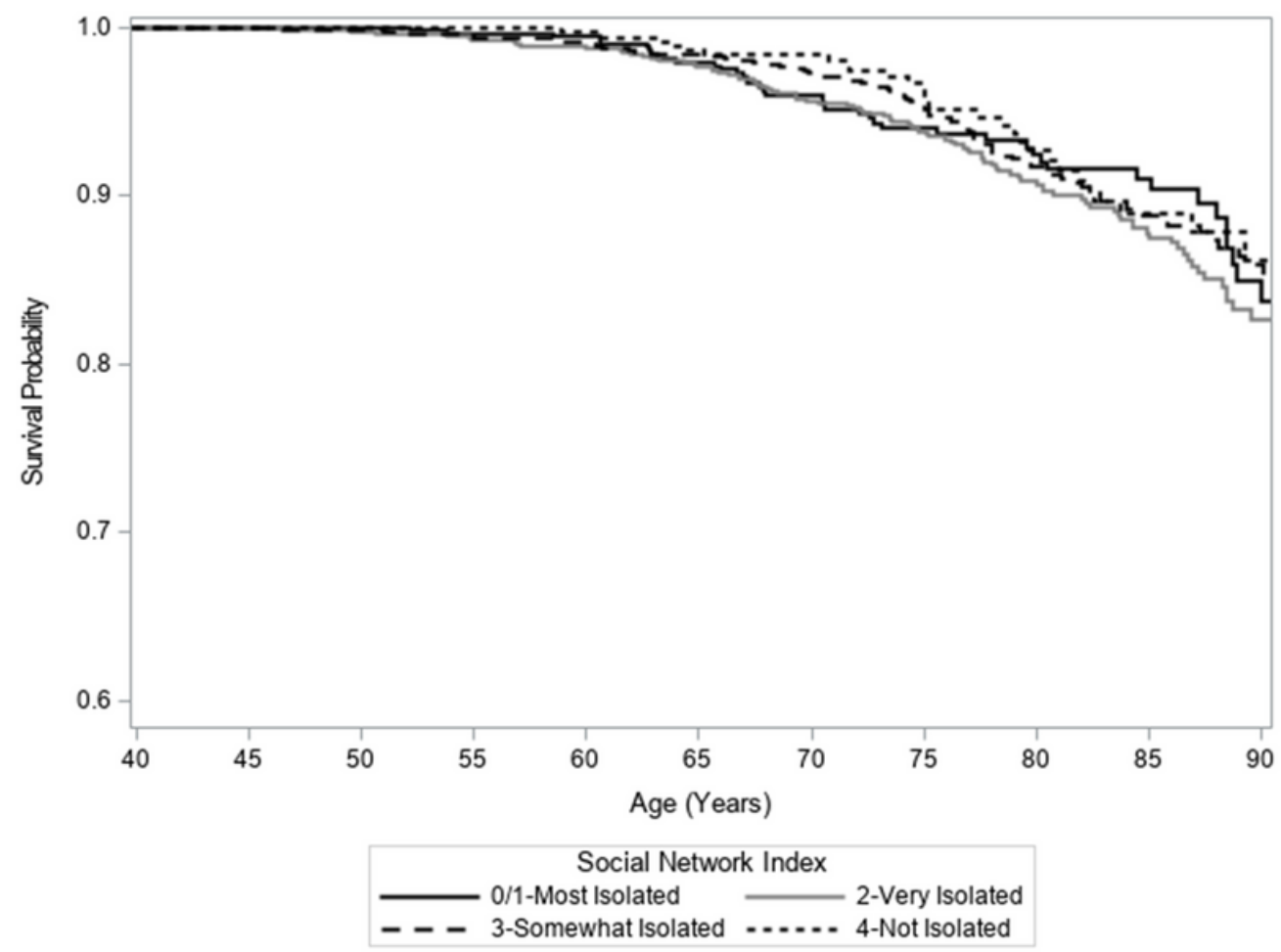

Total $\mathrm{n}=3466 . \mathrm{n}=562$ for ' $0 / 1$-Most Isolated', $\mathrm{n}=1162$ for '2-Very Isolated', $\mathrm{n}=1225$ for '3-Somewhat Isolated', $\mathrm{n}=495$ for '4-Not Isolated'.

\section{Figure 5}

Kaplan-Meier Estimates of Cancer Mortality by Social Network Index (log-rank $p=0.55)$ 